\title{
LEPROSY IN NEPAL
}

\author{
by N. D. Fraser, M.B. CH.B., D.T.M. \& H. \\ Medical Secretary, Mission to Lepers, London
}

In the Editorial of the July 1958 number of Leprosy Review, there appeared a report from Dr. P. J. Chandy with "News of Leprosy in Nepal".

It may be of interest to readers to bring this up-to-date in so far as more recent news has. been received from workers in Nepal.

Dr. Chandy remained in Nepal till the summer of 1958, having already made good contacts, established clinics, and assessed the size of the problem. Dr. J. C. Pedley then took over the work, continued to see patients at a number of clinics, and began the development of the site that had been granted to the Mission by the Government of Nepal. When Dr. Pedley proceeded on leave in 1960 Dr. Katherine Young, assisted by Miss Andrew, took charge of the medical work; while Mr. Dale Leathead, on loan from the Regions Beyond Missionary Union, took charge of the building operations, which he had been supervising since November 1959.

At the Leprosy Clinic begun by Dr. Chandy at the United Mission to Nepal Shanta Bhawan Hospital in 1956 records show that by February 1960, 312 leprosy patients had been registered, of whom 113 were reported by Dr. Pedley to be attending regularly on a weekly or monthly basis; Dr. Young reported that 87 attended on one day, of which number seven were new patients. At Bhatgaon, where a leprosy clinic has been established in connection with the medical work of the United Mission to Nepal, 78 patients had been registered by February 1960, of whom 46 were reported by Dr. Pedley to be attending regularly.

\section{Clinical work in the Kathmandu Valley}

At Anandaban, The Joyous Forest, the site of the new Mission to Lepers Kathmandu Valley Leprosy Hospital, 37 patients have been registered, with 11 putting in a regular attendance; since Dr. Young's arrival however a new centre has been opened in the valley at the village of Chapagaon; this saves the patients the extra three mile walk to the leprosarium, and already 20 patients are attending, with new patients appearing at each clinic.

At Kokhna, the Government leprosarium in the Kathmandu valley, there are reported to be 800 inmates; but 300 are said not to be suffering from leprosy. Dr. Young has been invited by the Ministry of Health to visit this segregation centre and to advise as to what arrangements can be made for the treatment of the patients, for while shelter and food have been provided, little in the way of effective treatment has been offered; many children already show signs of the disease. 


\section{Building Operations at Anandaban}

There have inevitably been delays in getting the building programme under way at Anandaban, but in June 1960 under Mr. Leathead's vigorous leadership the following position had been reached. Work was well advanced and wás proceeding on (a) Quarters for medical staff, and for a Nepalese construction manager. (b) Workshop, store, garage and generator house. (c) Temporary accommodation for patients to be admitted during June 1960. Further work was in hand on the installation of a "hydram" which involved a considerable engineering feat as a 90 -in. $(27.43 \mathrm{~m}$.) gully had to be bridged to carry a 9 -in. $(22.86 \mathrm{~cm}$.) pipe across; on staff quarters for a nurse; and for Nepalese workers; on further temporary accommodation for patients. Plans were under consideration for permanent quarters for patients; for additional staff quarters; and for the building of a hospital for the admission and treatment of those suffering from the more serious complications of the disease.

\section{Gorkha District}

Miss Nora Vickers, S.R.N., of the United Mission to Nepal, has sent news of the situation in the Gorkha District, five days walk from Kathmandu. The area is approximately 870 sq. miles (about 2,253 km. ${ }^{2}$ ) and the population of 124,000 includes people from all the castes of Hinduism, and from the hill tribes such as Gurungs, Magars and Tamang Lamas. During the past two years some 130 leprosy patients have been seen at a general clinic held on a mountain ridge at Amp Pipal. Those attending regularly amount to 55, but the tendency for more regular attendance is increasing. All types of the disease have been recorded, but gross deformities were few. Miss Vickers reports that there was some local resentment when it was realised that patients suffering from "The Great Disease" were being treated at this clinic, but threatened demonstrations were forestalled by visiting one or two gathering places and explaining, with the aid of posters, the nature of the disease, how it is spread, and the great benefits that modern treatment could bring to its victims.

\section{Tansen, W. Nepal}

Dr. Marjorie F. Foyle has sent word on the work of the United Mission to Nepal at Tansen, Palpa, West Nepal. The area covered is about 30,000 sq. miles (about $77,000 \mathrm{~km}^{2}$ ). No detailed leprosy survey has been possible, but monthly visits have been paid at the request of the health officials to the Government leprosarium at Malunga, six miles from Tansen; the colony consists of three twostorey brick buildings with mud floors. The storeys are divided into enclosures by mud walls, and in each enclosure there lives, as a rule, one family.

There were, in May 1960, 158 patients in the colony-75 men, 
46 women and 37 children. Of these $28 \%$ ( 4 men, 7 women and 34 children) show no sign of the disease. A team of workers from the United Mission Hospital at Tansen has paid monthly visits for the past two years. During April 1960 when Dr. Pedley accompanied the team, a survey of the patients showed $46 \%$ were Tuberculoid, and $54 \%$ Lepromatous. $62 \%$ of all cases suffered from deformity of one kind or another, and $63 \%$ had or have had ulcers. It is thought that the disease is widespread throughout the district.

\section{Pokhra District}

Dr. Ruth A. Watson writes of the work of the Nepal Evangelistic Band at Pokhra, 10 days' walk to the West of Kathmandu. To the North, as far as the Tibetan border, and to the West there are no medical facilities at all. Dr. Watson writes "Our patients come from every direction, but we have as yet been unable to do any detailed surveys of many areas. One survey was done, 3 to 5 days' walk to the North West where we already knew there was a great deal of leprosy. This survey confirmed to us the conditions under which these people were living, many of them in caves by the side of the trade route to Tibet where they beg from passing merchants".

\section{"Green Pastures"}

The Nepal Evangelistic Band began medical work in Pokhra in 1952, starting with a general dispensary. Leprosy patients were slow to come forward, but as confidence was established patients began to come, not so much from Pokhra itself, as from the villages in the surrounding hills. Some who came had too far to travel for regular treatment, others had been turned out of their homes, and soon a group of patients was living under a tree in the bazar. Feeling that a place should be secured for them as soon as possible, application was made to the Government, and permission was given to buy a tract of land four miles from the bazar. There was no time to erect permanent buildings, so a temporary shelter was put up and the first patients were admitted in September 1957 to the "Green Pastures" leprosarium. Here Miss B. C. Bailey, S.R.N., S.C.M., and Miss W. E. Lodge, S.R.N., S.C.M., live along with a Nepali family and a Nepali nurse to assist them. The father of the Nepali family was an outpatient and while attending for treatment became a Christian; the nurse was found to have developed leprosy while she was taking her training in the general hospital. Dr. Ruth Watson as Medical Superintendent pays weekly visits and operates as occasion demands. To date, A pril 1960, a total of 46 patients have been admitted (30 men, 16 women) and six have been discharged with "negative" certificates.

Meantime, the general dispensary begun in Pokhra in 1952 has grown to a hospital, to which leprosy patients come as out-patients. 187 men and 50 women have been registered, but attendance is far 
from satisfactory - the distances are too great, the paths too rough, and often the rivers too high. "We hope", writes Dr. Watson, "that later on it will be possible to start subsidiary clinics in strategic centres in each direction, run by ex-patients and supervised by regular visits from a doctor or nursing sister".

The majority of the leprosy patients are reported to be of the lepromatous type. Eye involvement is not common, but foot ulcers are a great problem because of the rough ground, and the fact that nearly all the people are farmers, with but little opportunity of finding alternative employment.

Doctors, nurses, physiotherapists, occupational therapists are all needed to help meet the increasing demands of this work-in India, in Africa, in Nepal, in Korea, in Hong Kong, and in many other countries. 